\title{
TAX E-FILING SYSTEM ACCEPTANCE LEVEL ON THE TAXATION COMPLIANCE: AN APPLICATION OF THE UTAUT APPROACH
}

\author{
Natasya $^{1}$; Elia Madatu Tandililing ${ }^{2}$; Michael Angelus ${ }^{3}$; Kevin ${ }^{4}$ \\ ${ }^{1}$ Ernst \& Young Indonesia \\ J1. Jendral Sudirman Kav. 52-53, Jakarta, Indonesia \\ ${ }^{2,3,4}$ Accounting Department, BINUS Graduate Program - Master of Accounting, Bina Nusantara University \\ J1. Kebon Jeruk raya No. 27, Kebon Jeruk, Jakarta 11530, Indonesia \\ ${ }^{1}$ natasya.natasya@id.ey.com; ${ }^{2}$ elia.tandililing@binus.ac.id; ${ }^{3}$ michaelangelus@binus.ac.id; \\ ${ }^{4}$ Kevin070@binus.ac.id
}

\begin{abstract}
This research aimed to analyze the acceptance level of the tax e-filing system on the tax compliance of the individual taxpayer. UTAUT had underpinned this research that consisted of the aspects of Performance Expectancy (PE), Effort Expectancy (EE), Social Influence (SI), and Facilitating Condition (FC). These factors were expected to trigger the taxpayer attitude which will be impact on their behavioral intention. Using a qualitative research approach, an interview with 16 individual taxpayers with certain criteria was conducted. The interview questions were derived from the UTAUT aspects. Moreover, all interview scripts segmented into three distinct classifications; age, gender, and occupation. The interview data were analyzed using Nvivo 12. The result shows that tax e-filing system is effective to stimulate the commitment of the participant, not only to use the system regularly and to report their tax return but also to fulfill their tax obligation voluntarily. The e-filing system increases participant productivity because it offers cost reduction and time-saving. Furthermore, it is easy to understand and effortless to use. However, SI has less impact on the participant' decision to use tax e-filing system since it is mandatory in accordance with the tax regulation. Regarding the FC, it is sufficient to develop people interest in using the e-filing system. This result could be a beneficial source for the Directorate General of Taxes to evaluate the e-filing implementation and for Indonesia citizen to actively involved in supporting Directorate General of Taxes policies to develop tax awareness throughout Indonesia.
\end{abstract}

Keywords: tax filing, e-filing system, acceptance level, taxation compliance

\section{INTRODUCTION}

The Indonesia Finance Ministry through Directorate General of Taxes (DGT) has undertaken an improvement to simplify the process of tax return (henceforth, it is called SPT/Surat Pemberitahuan Tahunan in Indonesia) submission in 2007, by modernizing the SPT submission mechanism along. This policy is one of the outcomes of Indonesia taxation reform which initiated by DGT in the same period. Along with the modernization of the SPT submission mechanism, DGT has also revitalized its tax office that is adjusted to the reform agenda and issued tax regulation with number 28/2007 concerning The General Provision and Procedures of Taxation. Yet, income tax and Value-Added Tax have been refined as well as tax incentives and facilities have been regulated to foster the national economic growth (DGT Annual Report, 2007). Regarding SPT submission, DGT previously has minimized the SPT form to support the self-assessment process conducted by Indonesia taxpayer, either individual or corporate taxpayer. However, advances in Information Technology (IT) followed by the increasing need of time and cost efficiency have triggered DGT to announce tax e-filing system adhere to Finance Ministy Regulation (PMK) with number 181/PMK.03/2007. It is concerning the form and content of the notice and procedure for making, filling, signing and submission of the tax return. 
Furthermore, DGT issues a derivative regulation with number 47/PJ/2008 regarding procedures of tax return submission and the extension of tax return submission electronically (e-filing) through application service provider. In afterward, e-filing system has officially merged with the DGT website in 2014. Referring to the e-filing system, it has been used by most of Indonesia taxpayer, particularly individual taxpayer. This is derived by the fact that the level of system usage has reached $80 \%$ of the total of SPT submission, which amounted to 10 million SPT on March 31, 2018, as the last date of SPT submission for the individual taxpayer. As a comparison, e-filing usage on March 31, 2017, has reached $69 \%$ of 9,7 million of SPT that have been submitted. However, several issues such as inadequate electronic media, lack of requirement understanding in terms of electronic SPT submission, and lack of IT knowledge in some region have led some of the individual taxpayers to manually submit their SPT (Neraca, 2018). Robert Pakpahan, the general director of DGT, adds that the e-filing system is still incapable of maintaining individual taxpayer compliance. This can be demonstrated through a comparison between the actual and the target of SPT submission. In 2018, the total of submitted SPT was 10 million or $70 \%$ of the SPT submission target which amounted to 14 million. This result, despite that it has increased by about 5\% compared to the achievement in 2007, has not been able to capture the ability of the e-filing system to step the individual taxpayer compliance up.

In order to obtain the whole picture of the role of e-filing system to transform the compliance behavior of an individual taxpayer, it is important to analyze the acceptance level of e-filing system by an individual taxpayer, which able to identify through their expectation and intention of the system. As a theoretical background of this research, the authors deploy the Unified Theory of Acceptance and Use of Technology (UTAUT). UTAUT is the result of an integration among eight existing technology acceptance models, such as technology acceptance model (TAM), the innovation diffusion theory (IDT), the theory of reasoned action (TRA), the theory of planned behaviour (TPB), the motivational models, a model of combining TAM and TPB, the model of PC utilization (MPCU), and the social cognitive theory (SCT) (Venkatesh et al., 2003). In essence, UTAUT is a theory that measures the level of acceptance of a technology by a group of users with behavioral intensity as a result of evaluating user behavior using these technologies (Thomas, Singh, \& Gaffar, 2013; Williams, Rana, \& Dwivedi, 2015).

Furthermore, UTAUT has been firmly approved that able to demonstrate a systematic description regarding the level of technology acceptance (Khechine, Lakhal, \& Ndjambou, 2016). Meanwhile, UTAUT segregates the assessment of the level of technology acceptance into four main elements; Performance Expectancy (PE), Effort Expectancy (EE), Social Influence (SI), and Facilitating Condition (FC). These elements are moderated with variables that describe the users (Venkatesh et al., 2003). PE indicates the level of trust the user has in technology in terms of the ability to solve the user problem. Furthermore, EE indicates the level of convenience experienced by users of technology. Thus, SI indicates the effectiveness of the environment or other social factors to encourage the user to use certain technologies. Ultimately, FC indicates the level of user confidence to use a technology based on the available infrastructure and other facilities (Mahzan \& Lymer, 2014).

Having been a theoretical basis to explain users intention in terms of a technology acceptance level, UTAUT has been broadly used in various fields, including taxation. In the healthcare sector in Surabaya, the level of e-health preference has been examined using UTAUT at one hospital with 100 participants (Sa'idah, 2017). In terms of PE, the e-health acceptance level is $92 \%$ because of its ability to facilitate a simple registration process. Referring to EE, the acceptance level has reached $96 \%$ from 50 participants in terms of easiness to obtain hospital services. Regarding SI factor, 50 participants argue that they are driven by other patients who have used the e-health system. This response leads to the acceptance level that has reached 74\%. Regarding FC factor, the level of e-health system acceptance has reached $76 \%$ because of its prominent feature and the fast response to provide a registration number. In terms of IB, however, e-health system is not to used intensely because some participants still prefer the traditional method as the consequence of their lack of knowledge in information technology. Hence, the acceptance level is only $80 \%$. 
Regarding public administration service sector, the level of e-government system acceptance has been examined with applying UTAUT approach in Palembang (Hartati, 2013). The result has inferred the e-government acceptance level is $90 \%$ due to its ability to improve citizen performance and accelerate the administrative processes (PE), able to understand easily and effortless (EE). In addition, the level of e-government usage tends to be more consistent (IB) in line with the invitation of the participant environment (SI) that has changed the participant paradigm regarding information technology (Attitude). Yet, the level of e-government system acceptance has been analyzed using UTAUT in Abu Dhabi (Al-Mansoori, Sarabdeen, \& Tchantchane, 2018). Conducted by quantitative approach, the result implies all the participants tend to apply e-government voluntarily as the significance level below 0,05 . In terms of PE, e-government is perceived to be able to minimize the time and costs of administrative management. In terms of EE, e-government does not have a significant impact because of the adequate level of understanding the participants have regarding information technology. However, e-government is proven to be effective because the local government obligates the use of the system (SI) and all participants are facilitated by the government regarding system usage instructions (FC). These responses ultimately lead to the participant commitment to use e-government continuously (IB).

The tax e-filing system had first been introduced in the United States (US) in 1986. Such an advanced tax submission procedure is required to bridge the US citizen with the US tax authority (IRS) in terms of taxation requirement more efficiently and effectively. This policy is made mainly to encourage US taxpayer compliance by reducing cost and time they require to fulfill their taxation obligation (Schaupp, Carter, \& McBride, 2010). In Indonesia, the emergence of tax e-filing system is inextricable with the higher demand of an adequate national income, whereby tax sector contributes $75 \%$ of the national budget (Directorate General of Tax, 2007). This system is introduced by DGT through DGT regulation with number KEP-05/PJ./2005 and, later, the regulation is refined through PER-47/PJ/2008 regarding procedures of tax return submission and the extension of tax return submission electronically (e-filing) through application service provider under the supervision of PMK regulation with number 181/PMK.03/2007.

Furthermore, the e-filing system has not yet merged with the DGT website at the beginning. Therefore, the merger process was undertaken in 2014 in accordance with DGT regulation with number PER-1/PJ/2014 concerning procedures of SPT submission with the e-filing system for the individual taxpayer whose applying tax form 1770S or 1770SS through DGT website. In addition, SPT submission on e-filing system not only utilized to tax form 1770S and 1770SS but also the tax form 1770 for the freelance taxpayer and 1771 for the corporate taxpayer. According to the regulation, the presence of the e-filing system is projected by DGT to simplify the SPT submission mechanism and eliminate the manual submission process through the DGT office or dropbox mechanism. Referring to the e-filing usage procedure, taxpayers are obliged to have e-filing registration number at first, known as 'E-FIN'. Previously, taxpayers are required to submit a letter of inquiry followed by attaching their tax identification number (henceforth, it is called NPWP in Indonesia) along with their national identification number to the tax office where the taxpayer has been registered. When the E-FIN number has been received, taxpayers must sign up for their participation in the e-filing system through the DGT website within 30 days after the E-FIN released date (Directorate General of Tax, 2018).

Following the development of the e-filing system, 8 million of the individual taxpayer have reported their SPT through e-filing system in 2017. This amount is $21 \%$ higher than the result in 2016, by which only 6 million of the individual taxpayer have applied the e-filing system as their tax reporting media. Nevertheless, the achievement is not aligned with the recorded compliance level of the individual taxpayer which increased only 5\% (Nurita \& Setiawan, 2018; Putera, 2018). The total amount of Indonesia individual taxpayer reaches 18 million whereby 14 million of the taxpayer is targeted to report their SPT. In fact, the realization is only $71 \%$ of the target, and $80 \%$ of the realized SPT submission is reported through the e-filing system. The other individual taxpayer, who remain submitted their SPT manually, infers that insufficient technical support from DGT has been the primary obstacle for them to 
use the e-filing system (Directorate General of Taxes, 2018). In this circumstance, Hidayat (1986) has propounded that effectiveness is the benchmark of target achievement. Accordingly, it can be concluded that DGT still has several challenges dealing with not only enhancing the level of individual taxpayer compliance in terms of SPT submission through e-filing system but also providing a more effective program for the taxpayer to alter their perception regarding the importance of tax e-filing system.

Regarding the UTAUT implementation on the tax e-filing system, there are several researches which have been undertaken. Firstly, US taxpayer attitude on the e-filing system has been examined using UTAUT approach added by several factors such as trust, risk perception, and optimism bias (Schaupp, Carter, \& McBride, 2010). The result confirms only two UTAUT factors (PE and SI) along with all additional factor have affected the taxpayer behavior in using the e-filing system. PE factor emphasizes the benefit of the system that providing accuracy in tax calculation. SI factor refers to the significance of community influence on the utilization of the e-filing system. Referring to the additional factor, the e-filing system is considered reliable and more secure in terms of maintaining data confidentiality. However, the overall result tends to be less informative due to interviewee limitation in this research that only students who become the research participant. Secondly, it has been examined the level of tax e-filing system adoption in Vietnam using three UTAUT factors and equip with Information System (IS) success model (Lu and Nguyen, 2016). Referring to the UTAUT model, the significance level of the system reaches 0,001 or below 0,05 as the benchmark of the significance level. The e-filing system able to meet the criteria of PE and EE in terms of usability, time efficiency, and cost saving of 137 individual taxpayer participant, as well as reducing the burden of participant tax obligation. Referring to IS approach, all participant feels secure to use e-filing system because of the efiling system ability to treat their taxation document confidentially, by which it encouraged them to use the system voluntarily and shifted from the traditional method (IB). Nevertheless, this research tends to focus only on the level of the e-filing system acceptance and unable to describe experiences the participant have while using the system as the consequence of applying the quantitative approach.

Thirdly, research regarding the level of the tax e-filing system preference has been conducted in Indonesia but limited to individual taxpayer intention (attitude) (Hakim, 2016; Dewi and Yadnyana, 2017). Thus, they have found that e-filing is firmly preferred in accelerating the task completion process (PE), facilitating the tax reporting process (EE) to generate a strong intention to use E-Filing (attitude). In accordance with the above researches, it can be demonstrated that UTAUT is significant to identify and measure the level of technology acceptance. By and large, all these researches have confirmed the system that concerning public service, including the tax system, is widely accepted. However, the findings are unable to capture in-depth public argument and experience related to the system due to its quantitative approach that only emphasizes the value of the level of the system acceptance.Align with the concept of the four factors in UTAUT, questions that able to raised in this research are: 1). what role does PE, EE, SI and FC have on determining the individual taxpayer attitude in applying E-Filing system? and 2). to what extent the individual taxpayer attitude able to influence the taxpayer behavioral intention in terms of their taxation compliance through E-Filing system?. To answer these questions and obtain a more sophisticated response, this research applies qualitative approach that it will provide a broader and detailed perspective of information rather than quantitative approach. The qualitative approach along with data collection method will be further described in the Methods Section.

This research applies the UTAUT model to analyze the level of the tax e-filing system acceptance as a determinant factor on the tax compliance of Indonesia individual taxpayer. Within the scope of this research, PE emphasizes that the e-filing system will be used if it can increase individual taxpayer productivity. EE means that whether e-filing is easy to understand and use, the individual taxpayer will continue to use the system. SI indicates that if people have eloquently use the tax e-filing system or government regulation regarding the procedures and dissemination of the use of e-filing has been completely understood, it will encourage individual taxpayer and prospective taxpayer to use efiling. FC emphasizes infrastructure readiness, such as access to communication, computer equipment, and other related supporting devices. It is followed by the availability of capable tax staff resources to 
conduct a workshop and public understanding of good technology that will able to encourage e-filing to be used consistently by individual taxpayer. In addition, researchers use the Attitude element as an indicator to confirm whether the individual taxpayer is willing and voluntary to use e-filing, referring to the four elements. After obtaining confirmation from the Attitude of an individual taxpayer, their behavioral intention in terms of the level of compliance with tax reporting using e-filing (IB) can be concluded. As a moderator, the variables used are age, gender, and individual taxpayer occupation. Thus, the theoretical framework to assist authors in exploring the level of e-filing system acceptance can be illustrated in Figure 1.

The theoretical framework demonstrates the role of all moderating variables; age, gender, and occupations to generate an adequate conclusion from individual taxpayer argument regarding the efiling tax system, adjusted with the four factors of technology acceptance criteria based on the UTAUT. Hence, confirmation of individual taxpayers' willingness to use the e-filing system can be obtained and thus it will affect changes in the individual taxpayers behavior, whether they will continuously apply the e-filing system. From this result, it can be justified the compliance level of the individual taxpayer on tax reporting using e-filing as well as their commitment to comply with their tax obligation.

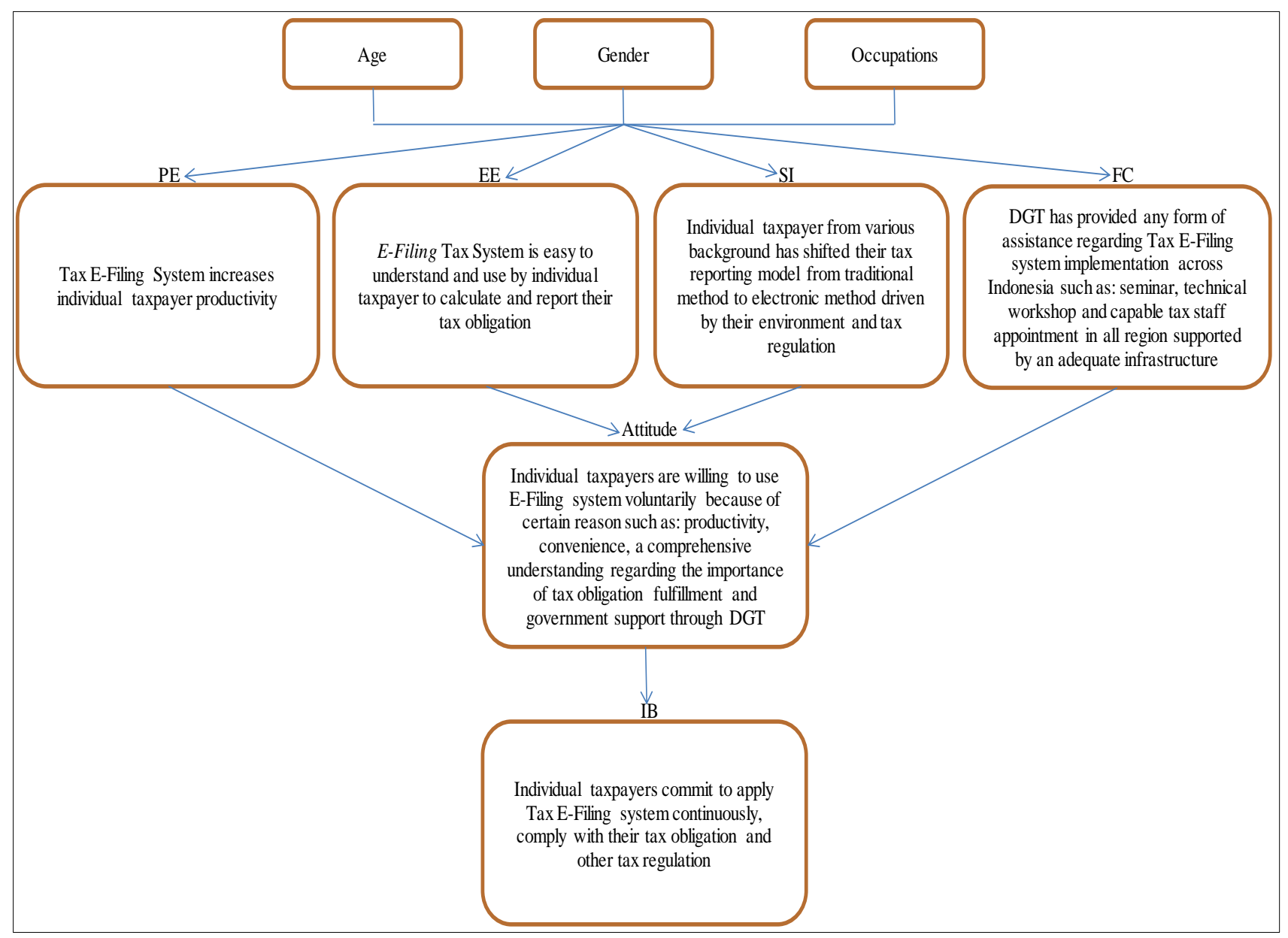

Figure 1 The Acceptance Level of the Tax E-filing System on the Taxation Compliance of Individual Taxpayer Source: Authors 


\section{METHODS}

This research applies descriptive qualitative research approach. Qualitative research requires a natural process to understand a phenomenon and investigators do not manipulate interest in the phenomenon are discussed (Patton, 2002). Meanwhile, the descriptive method is necessary to obtain comprehensive information about a phenomenon or an event (Saunders, Lewis, \& Thornhill, 2016). In connection with the data collection technique, this research applies Thematic Coding approach. Thematic Coding is utilized to identify a statement that constitutes a particular aspect, by which this research applies four UTAUT aspects. This approach uses a coding model of multiple data sources (Robson \& McCartan, 2016). Accordingly, this research uses primary data sourced from the interview with individual taxpayers and sampling process using purposive sampling method, by which the age category is determined between 24-64 years old and own NPWP. Explicitly, these participants are classified with who reports his tax privately or does not rely on another individual taxpayer.

Moreover, the selection of the age category based on the need to gain a comprehensive interview about the acceptance level of the tax e-filing system by the individual taxpayer and the benefit of the efiling system that will enhance individual taxpayer compliance on their tax obligation. The age category of individual taxpayer participant indicates maturity in understanding the tax regulation, as the age of 24 is able to have NPWP and must report their tax even though they were student due to the potential for additional income from interest income from the bank. The additional provision of this income stipulates in Law No. 36 of 2008 on Income Tax (Investment Coordinating Board, 2018). Moreover, the authors create a series of questions linked to the four UTAUT factors; PE, EE, SI, and FC including two additional elements; Attitude and Intentional Behaviour (IB). The detail of the working paper can be seen in Appendix A. In addition, the questions have been modified to harmonize with the UTAUT factors and research objectives.

The authors thus conducting an interview and an individual assessment at the same time. Yet, the interview process is recorded and made a transcript of the interview to be compared with the individual assessment, to assist the authors to make a preliminary conclusion. The time required for the interview process is three weeks. As an instrument of data processing, the qualitative data analysis software NVivo 12 is used. When processing the interview scripts using NVivo 12, the authors use keywords or coding to represent the participant response regarding the assessment of the tax e-filing system that has been classified into factors of UTAUT (PE, EE, SI, FC, Attitude, and IB). Keywords that reflect participant answers which correspond with PE aspects, for example 'system usage experience' and 'benefits'. Furthermore, keywords that reflect the answer which corresponds with EE aspect such as 'understanding the e-filing system workflow' and 'usability'. Then, keywords as a reflection of the answer to the SI aspect are divided into three terms; 'empowered by the community', ' empowered by regulation', and 'empowered by other factors'. Furthermore, keywords to describe answers that correspond with FC aspects include 'workshop', 'technical competencies', and 'infrastructure readiness'. In addition, the keyword that reflects the answers in conjunction with Attitude aspect is 'transition. Ultimately, the keyword describing the IB aspect is 'voluntary compliance'.

In order to adjust the resource statement with keywords of each element UTAUT, the authors make a segmentation of each response to attached on the keywords. Furthermore, the authors create a chart that demonstrates the percentage of each participant that has been classified for subsequent analysis according to the three categories; gender, age, and occupations. Referring to the participant occupation, the authors diversify into five distinct areas; housewives, students, experts, employees, and pensioners. 


\section{RESULTS AND DISCUSSIONS}

Participants who are willing to be interviewed are 16 individual taxpayers consisting of one retired civil servant (PNS), three housewives who have NPWP separated from their husbands, three experts who are consisting of two consultants and a doctor, two students, and seven employees. In terms of occupation category, it is projected to sharpen the diversification of individual taxpayer argument on the e-filing system, adhered to the activities and roles that are being carried out. The authors then use an identification code as the identity of the participant. Participant 1 is coded R1 and so on until the participant 16 is coded R16. Details regarding the participant profile can be seen in Figure 2. While from the occupation point of view, the analysis of the participant opinion can be seen in Figure 3.

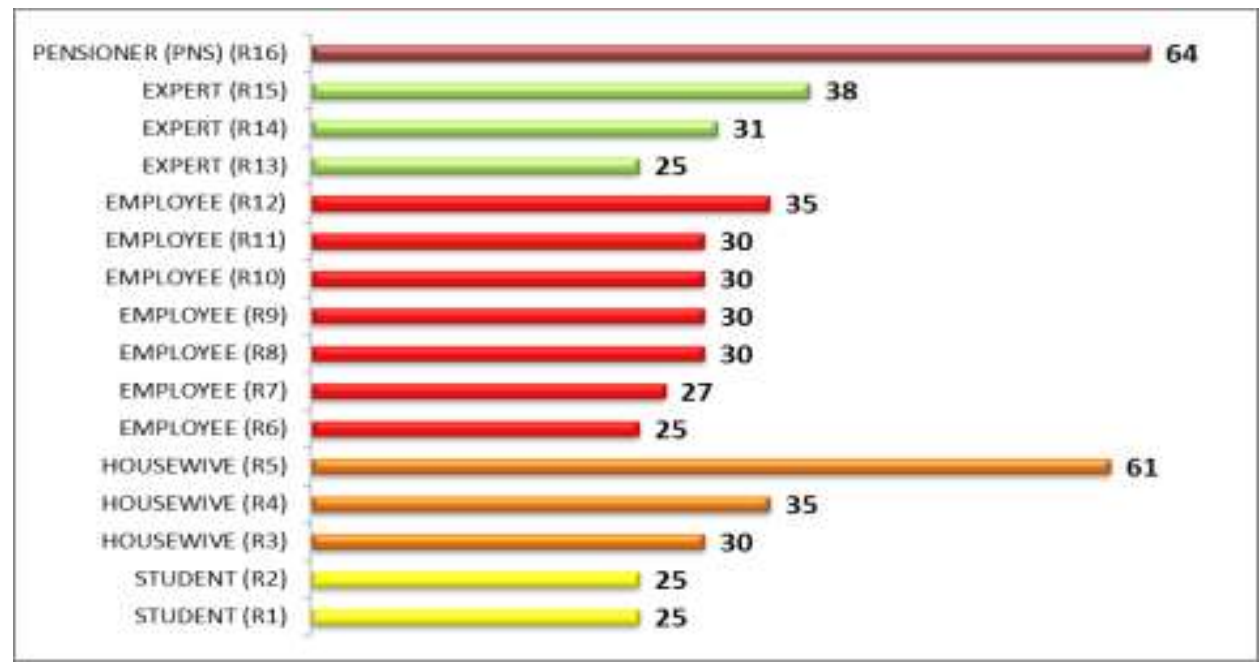

Figure 2 Participant Profile According to their Age and Occupation

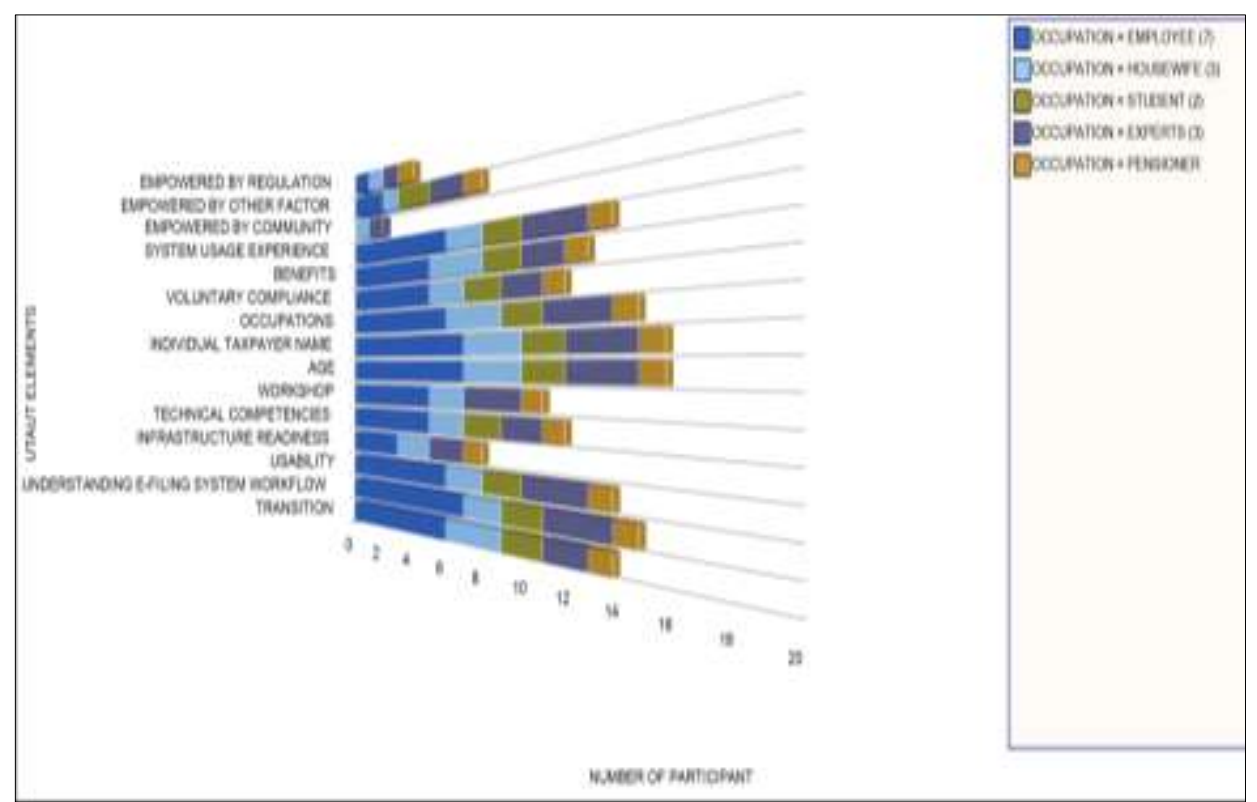

Figure 3 Assessment of the Tax E-Filing System According to the Occupation Category 
It can be seen from the chart that employees have given the majority response of the other occupation. Employee participants appear to be more experience in using the e-filing system than other groups triggered by the demand comes from their workplace that required tax e-filing system usage. With a sufficient level of experience, the employee participants have gained significant benefits. The same response is also experienced by another participant who stated that the e-filing system has helped them related to time management, costs, and filing management. Retired PNS participant (R16) explicitly states that e-filing is not only beneficial for the individual taxpayers but also tax officers in terms of facilitating the mapping process of compliant and non-compliant taxpayers, potential new taxpayers through extensification program and potential tax mapping. The following statement is R16 response:

"so, we did feel that reporting with the old system compared to the current e-filing system, in fact e-filing system really help taxation officers...this tax officer means DGT employees [...] ... very helpful for the tax officers in terms of their service..the extensification becomes effective and the individual taxpayer tax calculation pattern is detected, whether there is an avoidance or evasion."

Another interesting response, employee participant (R7) chose tax reporting manually because of their inability to understand electronic tax reporting very well even though their experience and understanding of taxation are sufficient. Nevertheless, this participant believes that e-filing is beneficial, especially related to the allocation of time and good accessibility. The complete R7 argument is:

"great, so the government has begun to put all the tax regulations in order. You don't need to come to the tax office anymore to queue up to submit your annual tax return ... [...] E-filling, i know, but I'm still not familiar to fill it in - [...] I still prefer manually if possible. Because of that, the manual system is easier. For tax consultant services, I might want to think about it first, that will be another cost $[\ldots]$ Yes we have to be consistent. Because we have already registered online."

Having an adequate experience, this participant has a good understanding of tax e-filing and have no issues in its operation. This is quite a contrast response compared to an interviewee who is a housewive and two interviewees who are experts. These three participants are assisted by other parties, but they agree that the e-filing system is not difficult to understand and they commit themselves to try the system on the next tax return reporting period, as the opinion of expert participants (R15):

"honestly because I got helped, I do not really understand how to fill it by myself ... but since everything is already electronically assisted, it is now easier with e-filling. By using e-filling, it is not complicated. We do not have to repeatedly consulting to the tax office... initial consultation may be necessary when filling it for the first time, after that is already run by the system ... so it is easier for those who fill it ... [...] I will definitely try ... if there is a problem, constraints and a solution provided for it I will try ... there has to be an assistance so must be easy to learn."

Having sufficient experience and understanding of the use of e-filing, making the employee participants have a critical argument about the condition of the facility for the implementation of efiling. Interestingly, the employee participant and other occupation have seen the issue of the e-filing socialization that is not equally distributed and right on target, followed by an explanation from the DGT tax officer regarding technical workshop of the e-filing implementation which is not yet sufficient. These two factors are needed to improve so that it will enable the e-filing system nationalization policy work well, although they also criticize the availability of human resources for tax officers and the availability of inadequate electronic devices and communication networks in several regions in Indonesia, particularly in eastern Indonesia. Regarding the SI factor, the employee participant prefers the publication of the percentage of e-filing usage as the main driving factor for taxpayers to use e-filing. 
This response is different from the students, experts, and retired civil servants opinion that enforcing rules accompanied by punishment will effectively encourage the transition to the use of the e-filing system. Referring to the housewives, the expert community has an equally important role in influencing other community to understand and use the e-filing system and comply with its tax obligations. Although all participant agree that there are still some weaknesses in the implementation of the e-filing system, they state that the e-filing should be nationalized and become a single system for tax reporting. In addition, all participants commit to obediently use the e-filing system and be transparent in reporting taxes.

An analysis of the level of e-filing system acceptance from the gender perspective becomes important in consideration with diverse responses following different character and mindset. Thus, the individual taxpayer assessment of e-filing can be seen in Figure 4.

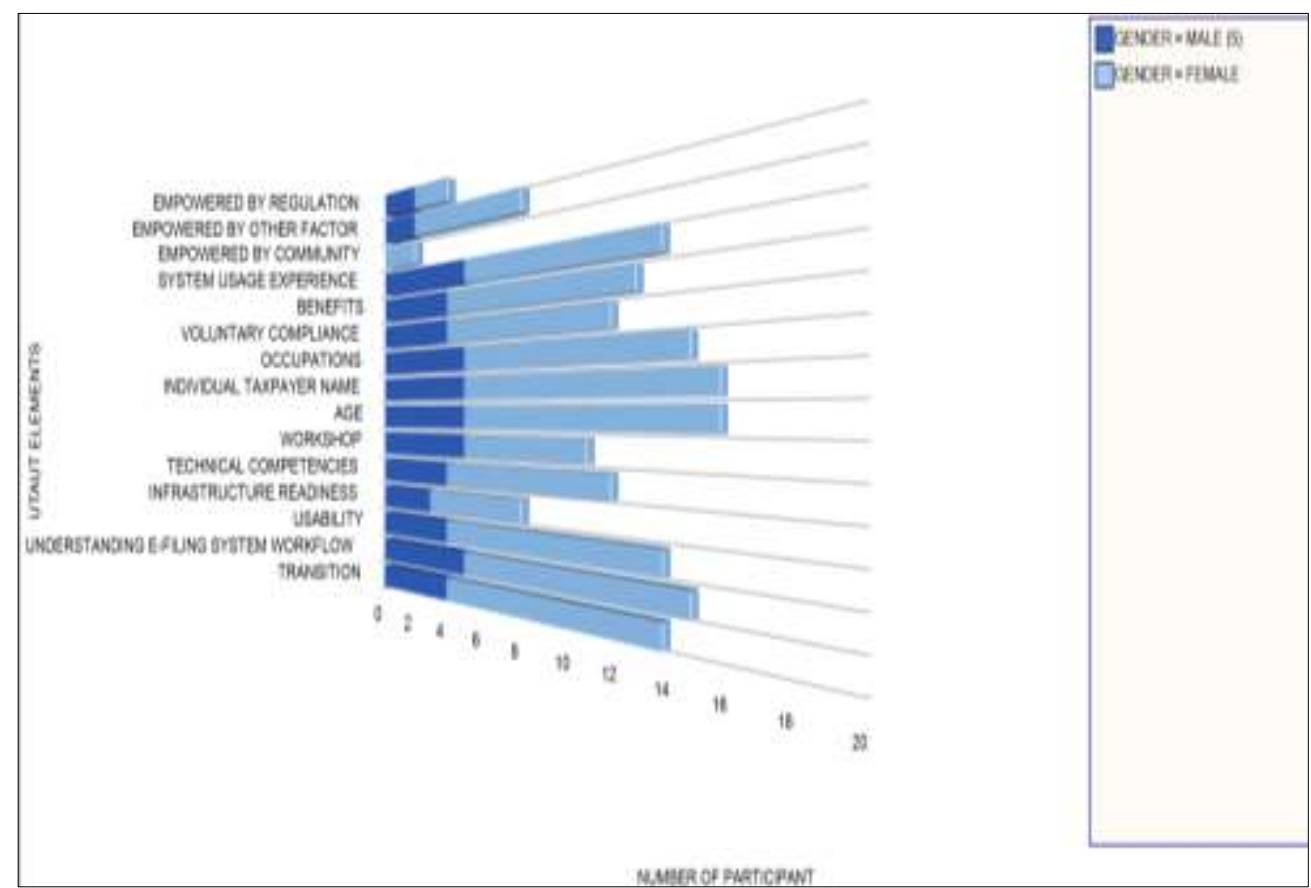

Figure 4 Assessment of the Tax E-Filing System According to the Gender Category

Participant in this research comprises of five males and 11 females. According to the chart, it shows the number of responses according to the proportion of participant per gender. If it is examined of each aspect of the UTAUT element, the female participants are dominant in delivering a statement that e-filing provides more benefit, it is easy to understand and not difficult to operate. This opinion is directly proportional to the number of female participants who dominate employee and student professions apart from housewives. This opinion also confirms the adequate experience the participants have, even though there are one male and two female participants who have not directly used e-filing but are committed to use it in the future. The interesting finding is that female participant prioritizes persuasive methods from people who are experienced in using e-filing, followed by news reporting and law enforcement. In general, housewive participants have activities that are appropriately related to social activities other than activities at home. The authors see that there is a positive correlation between the types of activity of the participants with responses regarding social factors to encourage the individual taxpayer to use e-filing following by the statement of one of the housewife participant (R5): 
"I am involved in social activities, become a treasurer in the Pasundan Church and also for a church community ... other than just being as a housewife ... [...] that is a rule, but besides that we are also a part of the community ... the government has been repeatedly promoting about E-Filling... friends will certainly invite and teach us if it is really confusing."

Regarding the Attitude, female participants are more convinced that e-filing is worth to be nationalized than male participants. Male participants emphasize the need for evaluation regarding the implementation of the e-filing socialization and training for the individual taxpayer before it is being nationalized. In addition, manual SPT submission is still needed while ensuring all taxpayers understand and able to use the e-filing system. However, both male and female participants agree to obey and be more disciplined using e-filing and more transparent regarding their income data. In terms of the readiness of supporting facilities for the e-filing system, women highlight the issues of technical capabilities that needed to be accommodated by DGT tax officers in the availability of computer devices and the internet to facilitate the learning process of using tax e-filing system. On the other hand, male participants emphasize on the socialization of the regulation because almost all male participants argue that in the era of globalization, it is not difficult to access all relevant information. They argue that the tax officers must organizing the e-filing socialization, either from the DGT itself or assign tax officers to come to the regional representative office and carry out a regular seminar or technical workshop. The result of the individual taxpayer assessment of tax e-filing system according to the age category can be seen in Figure 5.

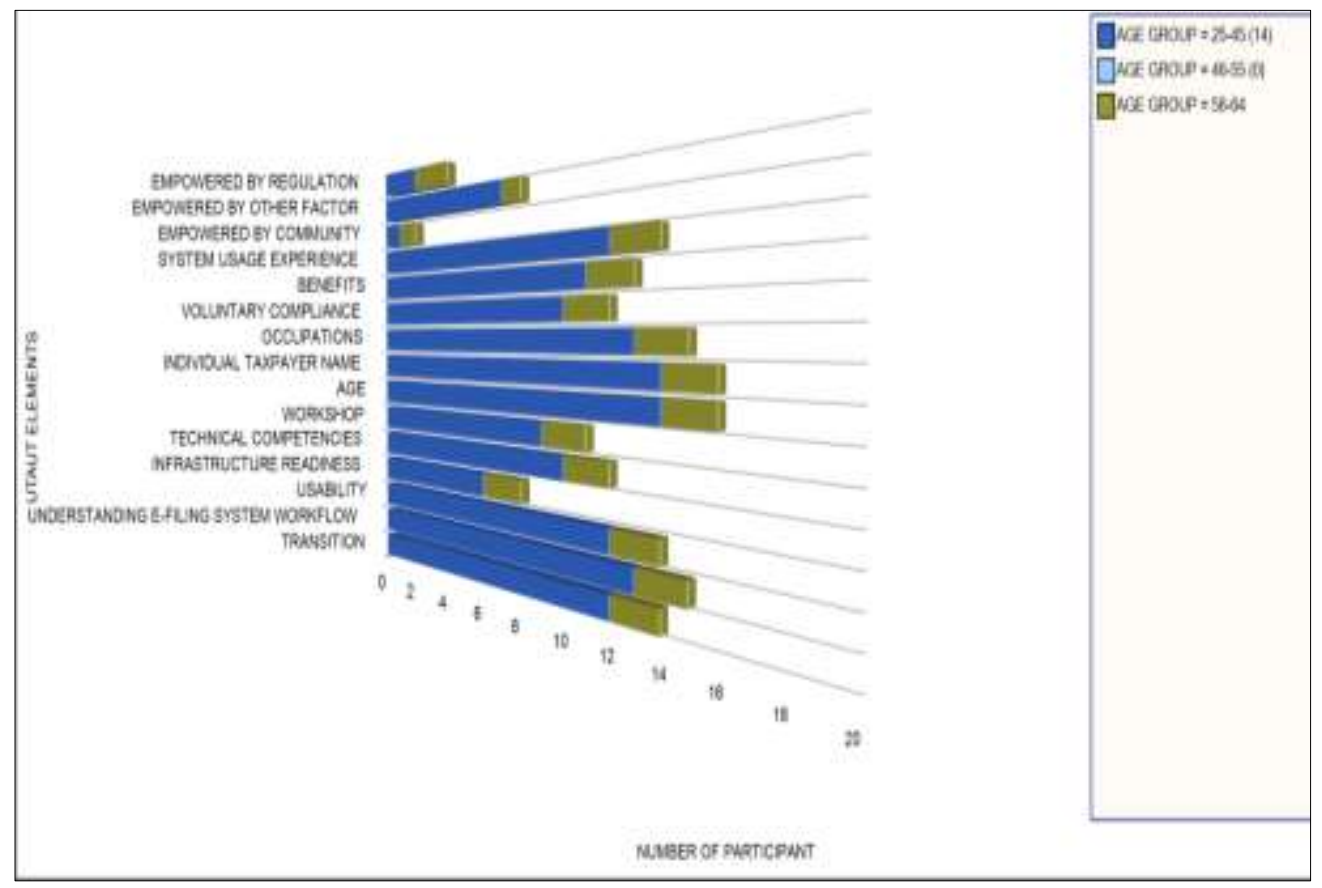

Figure 5 Assessment of the Tax E-Filing System According to the Age Category

In this research, participants have diverse age. Student participants are 25 years old, followed by employees who are in the age range of 25-35 years old. Then, experts in the age range of 25-38 years old. The age range of housewive participants between 30 and 61 years old. A retired civil servant is 64 years old. With the classification of the age range that has been made by authors, the age of 25-38 years is categorized in the group '25-45 years'. In addition, participants with age 61 to 64 years old is entered the '56-64-year-old' group. The age group of ' $25-45$ years' is marked with color blue, while the age 
group of ' $56-64$ years' is marked with color green. The authors' consideration in age group segregation emphasizes on the evaluation of the e-filing system based on productive and unproductive age, but it is classified as an active taxpayer because the participant owns NPWP. Referring to Figure 5, it shows that the age group between 25-45 years old dominate response related to the e-filing system using the UTAUT perspectives. In general, the two age groups state that the e-filing system has enabled them to maintain their productivity. Furthermore, the age group of 25-45 years old more emphasizes on timesaving while the other group points out cost saving and file management as the benefit of tax e-filing system. Referring to the system usage experience, it can be seen that the age group of 25-45 years old are more experienced because of the demand comes from their place of activity. On the other hand, the age group of 56-64 years old tends to have less experienced. However, both participants are willing to voluntarily learn and use tax e-filing system in the future.

Regarding the social factor, it is clear that regulation and its publication becomes the most important issue for the age group of 25-45 years old as it is stated in the following statement of expert participant (R14):

"Referring to the middle-class people who are more tax literate ... let say to encourage ... yes ... because Indonesia taxpayer sometimes need to be forced and punished ... to obey, if not they will be careless"

Meanwhile, another group argues that the active role of the community and tax officers as a driven factor for the transition process of tax return reporting from manual to e-filing model. The age group of 56-64 years old are dominated by retired civil servant and housewives. In their daily activities, this group more interacts with a various layer of society in the form of social activity. Referring to this, the authors find a close relationship between their activities and the expressed opinion regarding the social factor. In the context of the readiness of e-filing supporting facilities, both groups collectively state that the readiness of capable DGT tax officer followed by availability in terms of equipment and a stable network, as well as the improvement of individual taxpayer technical capabilities, become the crucial factors in implementing the tax e-filing system. Furthermore, the two groups agree that it is time for tax reporting mechanism to shift from manual to e-filing model. In addition, they will voluntarily comply and be more disciplined to disclose assets and taxes to be paid.

With reference to the overall responses as well as arguments obtained from the three assessment model using UTAUT factors, it can be concluded that tax e-filing system is firmly accepted by 16 participants. This is aligned with participant commitment to voluntarily move from manual submission process to the advanced system. With reference to the research objectives, meanwhile, the research findings will be described related to each UTAUT factor. Firstly, PE directly contributes to the transition of participant behavior (Attitude) to use tax e-filing system. Of the three assessment categories (occupation, age, and gender), all of them demonstrates the benefit of an e-filing system; it is supportive in terms of time-saving and cost efficiency. Hence, participants are voluntary and willing to use e-filing as their tax reporting media. This result is consistent with the research outcome of Schaupp, Carter, and McBride (2010); Hakim (2016); Lu and Nguyen (2016); and Dewi and Yadnyana (2017), as taxpayer will voluntarily use the e-filing system if the tax submission process is more fluid and efficient than the manual process.

Secondly, EE directly contributes to the participant behavior (Attitude) to apply the e-filing system. Although a small number of participants are still assisted by others in filling out and submit their SPT electronically, these participants have shown their attempt and willingness to be able to personally try the e-filing system and consistently report their SPT through the e-filing system. The underlying factor is that the e-filing system is easy to understand and operate. Furthermore, the automation process of tax calculation and the accuracy of tax calculation have assisted participants to clearly understand the potential tax obligations. In addition, e-filing is useful in terms of managing the SPT document because it is filed electronically and paperless. This result has a more comprehensive 
dimension of response rather than the research outcome of Hakim (2016), Lu and Nguyen (2016), and Dewi and Yadnyana (2017), where the EE aspect in the previous three research only emphasize on the ease of applying e-filing.

Thirdly, SI directly contributes to the behavior of the participant (Attitude) to use e-filing. Referring to housewive and retired civil servant participants, invitation and advocation from the community are considered to be more sufficient to influence these participants to voluntarily understand and learn about the tax e-filing system. This response is similar with Schaupp, Carter, and McBride (2010) findings. Referring to students, employees and experts participant, extensive publication on the level of e-filing usage and more intensive e-filing socialization from DGT will deliver a significant impact on them to switch to use the e-filing system. This argument tends to be more informative and clear to justify the role of SI to determine the acceptable level of the e-filing system than Dewi and Yadnyana (2017) findings. The research participant only emphasizes on an introduction of e-filing system from other associates and their social status, ignoring the possibility of the transition process in terms of tax submission method in the environment around the participant. Meanwhile, Lu and Nguyen (2016) do not specifically explain the role of SI in relation to the e-filing system usage intention in Vietnam.

Fourthly, FC also directly contributes to a change in participant behavior (Attitude). Participant opinion from all categories (age, occupation, and gender) are more critical to the limitations of capable tax officer availability, infrastructure readiness in some areas and technical workshop or the e-filing system socialization. According to participant argument, if the facility can be provided adequately, it will be able to encourage the process of the e-filing system nationalization and discipline in using the E-Filing system, particularly for the participant itself. This result is coherent with Dewi and Yadnyana (2017) findings. However, Hakim (2016) in his research does not clearly evaluate FC for the use of efiling so that the results of his research are not related to aspects of FC. Meanwhile, Schaupp, Carter, and McBride (2010), as well as Lu and Nguyen (2016), ignore the FC factor as the determinant factor of e-filing implementation because of a more well-established infrastructure provided in each country.

Fifthly, Attitude of the participant directly contributes to the participant IB. Although there are still limitations and weaknesses in the e-filing system implementation, this does not become an obstacle for the participant to voluntarily report their taxes through the e-filing system and transparently report their source of income. The benefits and usefulness provided from the e-filing system are able to convince the participant to be more disciplined in using the e-filing system and comply with their tax obligation. This result is coherent with the positive contribution of PE, EE, SI, and FC toward the change of the attitude of 16 individual taxpayer participant to use e-filing. In contrast, Lu and Nguyen research (2016) findings suggest that whether information confidentiality as the FC element able to provided by the Vietnam tax e-filing system, the participant would be attracted to shift (Attitude) from the manual submission process to electronic process and consistently uses e-filing system (IB).

\section{CONCLUSIONS}

By and large, tax e-filing system has widely accepted by this research participant because of its several significant effects. It is beneficial for individual taxpayers to simplify their tax return reporting process. It saves time and able to reduce costs; hence it has increased taxpayer productivity. The tax efiling system is accessible and capable of delivering an accurate tax calculation. Accordingly, it has stimulated the individual taxpayer participant to commit themselves to comply with tax e-filing system and be more disciplined in reporting their taxation obligation. Referring to the change of taxpayer attitude, it is not relied only on the benefit that has been received but also from invitation derived by the community as well as DGT officer regarding the importance of reporting tax return through the e-filing 
system. In addition, the e-filing system socialization and technical workshop are followed by infrastructure readiness that is conducted by competent DGT tax officers are vital to develop taxpayer awareness of their taxation obligation. It is also necessary to balance the need for national income and taxpayer expectation in which the reporting mechanism will be simplified. Ultimately, the compliance level of the individual taxpayer to voluntarily submit their SPT through the e-filing system highly depends on their attempt and willingness to shift from the traditional model to the electronic model. This transition will occur if taxpayers requirement is accommodated, such as comfortability, safety, and a comprehensive understanding while using tax e-filing system.

As a recommendation, DGT needs to intensify their socialization and workshop program regarding the need of Indonesia citizen, particularly individual taxpayer, to comply with tax regulation and promote the benefit of tax disclosure through e-filing system throughout Indonesia. Furthermore, electronic infrastructure needs to provided equally in all regions in Indonesia. Yet, the appointment of a capable tax officer is vital to develop people awareness on their understanding regarding taxation. On the other hand, the community should support government policy in terms of e-filing system nationalization throughout Indonesia. Furthermore, experience in relation to electronic tax submission model needs to be shared with other parties and invite them to comply with Indonesia taxation regulation. One of the regulation is obligate all taxpayer to submit their SPT through the e-filing system.

\section{REFERENCES}

Al-Mansoori, K. A., Sarabdeen, J., \& Tchantchane, A. L. (2018). Investigating Emirati citizens' adoption of e-government services in Abu Dhabi using modified UTAUT model. Information Technology and People, 31(2), 455-481. https://doi.org/10.1108/ITP-12-2016-0290.

Dewi, N. K. L. R. D, \& Yadnyana, I. K. (2017). Faktor-faktor yang mempengaruhi minat dan perilaku penggunaan sistem e-filing di kota Denpasar dengan model UTAUT. E-Jurnal Akuntansi Universitas Udayana, 21(3), 2338-2366. https://doi.org/10.24843/eja.2017.v21.i03.p23.

Directorate General of Taxes. (2007). Annual report 2007. Retrieved December $15^{\text {th }} 2018$ from http://www.pajak.go.id/sites/default/files/Annual_Report\%202007.pdf.

Directorate General of Taxes. (2018). E-Filing: Cara mudah cepat dan aman lapor pajak. Retrieved December $15^{\text {th }} 2018$ from http://www.pajak.go.id/content/article/E-Filing-cara-mudah-cepat-danaman-lapor-pajak.

Hakim, M. M. (2016). Analisis model penerimaan pengguna sistem pelaporan pajak online. Simetris : Jurnal Teknik Mesin, Elektro Dan Ilmu Komputer, 7(1), 365-372. https://doi.org/10.24176/simet.v7i1.526.

Hartati, E. (2013). Analisis faktor - faktor yang berpengaruh terhadap efektivitas penerapan egovernment dengan menggunakan metode UTAUT (Unified theory Of acceptanced use of technology) di kota Palembang. Seminar Nasional Teknologi Informasi Dan Multimedia. Yogyakarta, Indonesia. pp. 7-12.

Hidayat. (1986). Teori efektivitas dalam kinerja karyawan. Yogyakarta: Gajah Mada University Press.

Investment Coordinating Board (BKPM). (2018). Income tax regulation number 36/2008. Retrieved December $28^{\text {th }} \quad 2018 \quad$ from https://www.bkpm.go.id/images/uploads/prosedur_investasi/file_upload/UU_36_2008.p. 
Khechine, H., Lakhal, S., \& Ndjambou, P. (2016). A meta-analysis of the UTAUT model: Eleven years later. Canadian Journal of Administrative Sciences, 33(2), 138-152. https://doi.org/10.1002/cjas.1381.

Lu, N. L., \& Nguyen, V. T. (2016). Online tax filing - E-government service adoption case of Vietnam. Modern Economy, 7(12), 1498-1504. https://doi.org/10.4236/me.2016.712135.

Mahzan, N., \& Lymer, A. (2014). Examining the adoption of computer-assisted audit tools and techniques. Managerial Auditing Journal, 29(4), 327-349. https://doi.org/10.1108/maj-05-20130877.

Neraca. (2018). Sistem pelaporan e-filing perlu dievaluasi - Ditjen pajak terima lebih 10,5 juta laporan SPT WP pribadi. Retrieved December $14^{\text {th }} 2018$ from http://www.neraca.co.id/article/99267/sistem-pelaporan-E-Filing-perlu-dievaluasi-ditjen-pajakterima-lebih-105-juta-laporan-spt-wp-pribadi-2017.

Nurita, D., \& Setiawan, K. (April $2^{\text {nd }}, 2018$ ). Jumlah wajib pajak pribadi pelapor SPT masih di bawah target. Tempo.Co. Retrieved December $15^{\text {th }} 2018$ from https://bisnis.tempo.co/read/1075511/jumlah-wajib-pajak-pribadi-pelapor-spt-masih-di-bawahtarget.

Patton, M. Q. (2002). Qualitative research \& evaluation methods (Third Edition). London: Sage Publications.

Putera, A. D. (April $4^{\text {th }}$, 2018). Rasio kepatuhan pelaporan SPT wajib pajak orang pribadi meningkat. Kompas.Com. $\quad$ Retrieved December $15^{\text {th }} \quad 2018$ from: https://ekonomi.kompas.com/read/2018/04/02/180752626/rasio-kepatuhan-pelaporan-spt-wajibpajak-orang-pribadi-meningkat.

Robson, C., \& McCartan, K. (2016). Real world research (Fourth Edition). United Kingdom: John Wiley \& Sons.

Saunders, M., Lewis, P., \& Thornhill, A. (2016). Research methods for business students. New York: Pearson.

Sa'idah, N. (2017). Analisis pemgunaan sistem pendaftaran online (e-health) berdasarkan Unified Theory of Acceptance and Use of Technology (UTAUT). Jurnal Administrasi Kesehatan Indonesia, 5(1), 72-81. https://doi.org/10.20473/jaki.v5i1.2017.72-81.

Schaupp, L. C., Carter, L., \& McBride, M. E. (2010). E-file adoption: A study of U.S. taxpayers' intentions. Computers in Human Behavior, 26(4), 636-644. https://doi.org/10.1016/j.chb.2009.12.017.

Thomas, D. T., Singh, L., \& Gaffar, K. (2013). The utility of the UTAUT model in explaining mobile learning adoption in higher education in Guyana. International Journal of Education and Development using Information and Communication Technology (IJEDICT), 9(3), 71-85.

Venkatesh, V., Morris, M. G., Davis, G. B., \& Davis, F. D. (2003). Quarterly, 27(3), 425-478.

Williams, M. D., Rana, N. P., \& Dwivedi, Y. K. (2015). The unified theory of acceptance and use of technology (UTAUT): A literature review. Journal of Enterprise Information Management, 28(3), 443-488. https://doi.org/10.1108/JEIM-09-2014-0088. 


\section{Appendix A}

Interview Working Paper

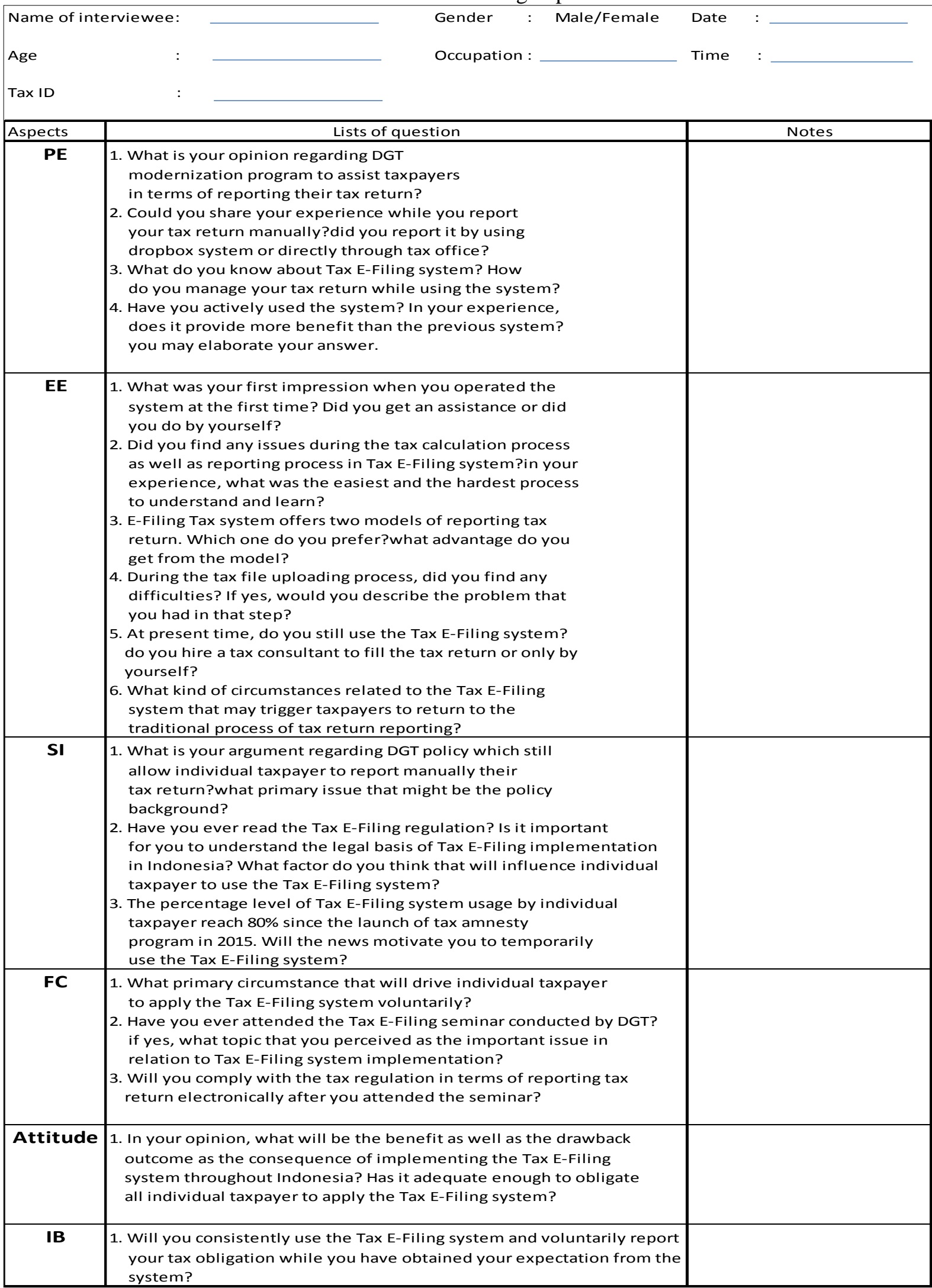

